\title{
Native eelgrass Zostera marina controls growth and reproduction of an invasive mussel through food limitation
}

\author{
Bengt J. Allen ${ }^{1,3, *}$, Susan L. Williams ${ }^{2}$ \\ ${ }^{1}$ Department of Biology, San Diego State University, San Diego, California 92182-4614, USA \\ ${ }^{2}$ Department of Environmental Science and Policy, and Bodega Marine Laboratory, University of California at Davis, \\ PO Box 247, Bodega Bay, California 94923-0247, USA \\ ${ }^{3}$ Present address: Department of Ecology and Evolution, State University of New York at Stony Brook, Stony Brook,
} New York 11794-5245, USA

\begin{abstract}
In southern California, native eelgrass Zostera marina L. and the invasive non-native mussel Musculista senhousia have dynamic complex interactions. Although high densities of M. senhousia inhibit the growth of eelgrass, mussel survival and growth decline with increasing eelgrass shoot density and patch size. The correlation of these eelgrass attributes with local concentrations of chlorophyll $a$ and water flow speeds suggested that the mussels, which feed on phytoplankton delivered by water currents, might suffer food limitation inside large eelgrass beds. By supplementing phytoplankton to M. senhousia living in eelgrass, we confirmed this hypothesis: mussels grew $50 \%$ faster when food availability was enhanced. Lab and field experiments investigating the effects of food limitation on growth and reproduction of $M$. senhousia showed that mussels respond by reducing shell growth, and subsequently fecundity. We found no evidence that mussels reallocated resources preferentially to reproduction when food was limited. Our results highlight how the effects of anthropogenic perturbations that currently threaten eelgrass populations directly could be magnified by interactions with a non-native species. Eelgrass habitat fragmentation and increasingly frequent phytoplankton blooms resulting from coastal development and eutrophication have welldescribed direct negative effects on eelgrass. By increasing phytoplankton availability to $M$. senhousia, such perturbations also indirectly affect eelgrass by acting to enhance mussel survival and growth, magnifying the negative effects of the mussel on Z. marina.
\end{abstract}

KEY WORDS: Musculista senhousia · Food limitation · Resource allocation · Non-native species · Zostera marina $\cdot$ Multiple perturbations

Resale or republication not permitted without written consent of the publisher

\section{INTRODUCTION}

Estuaries are ecologically and economically important ecosystems that support a myriad of commercial, recreational, and military activities. Many estuarine habitats are exhibiting marked changes in community structure and function as a result of multiple anthropogenic perturbations, superimposed on natural change (NRC [National Research Council] 1995, Short \& Neckles 1999). Of particular concern are perturbations to productive estuarine wetlands such as sea- grasses and salt marshes (Dennison et al. 1993, Short \& Wyllie-Echeverria 1996). Seagrasses are marine flowering plants that form extensive meadows in shallow waters, providing ecologically important functions including primary production, filtration of land runoff, sediment stabilization, and nursery habitat for many fisheries species (McRoy \& Helfferich 1977, Phillips \& McRoy 1980, Williams \& Heck 2001). Seagrass habitat consequently is protected under the US Coastal Zone Management Act and the Clean Water Act. Nevertheless, loss of such habitat is accelerating in the USA and 
worldwide, due to eutrophication and subsequent algal blooms, disease, physical disturbance, and interactions with non-native species (Peterson et al. 1987, Short \& Neckles 1999, Hauxwell et al. 2001, Williams \& Heck 2001).

In San Diego Bay, a highly disturbed urban estuary in southern California, USA, a native seagrass, Zostera marina L. (eelgrass), is conditionally threatened by the invasive marine bivalve Musculista senhousia (Benson 1842). At high densities, $M$. senhousia interferes with eelgrass vegetative growth (Reusch \& Williams 1998), the most important mode of reproduction in local $Z$. marina populations (Ewanchuk 1995). M. senhousia is a small mytilid mussel native to east Asia that has successfully spread to New Zealand, Australia, the Mediterranean, and the Pacific coast of North America (reviewed in Crooks 1996). First reported in southern California in the mid-1960s (MacDonald 1969), the abundance of $M$. senhousia has increased dramatically in the past decade (Crooks 1996) such that the mussel is now the most abundant macroinvertebrate in terms of biomass at many sites, occurring at densities as high as $15000 \mathrm{~m}^{-2}$ (Reusch 1998). Like other mytilid mussels, $M$. senhousia feeds by filtering phytoplankton from the water column, and has high fecundity and a planktonic larval stage lasting several weeks (Kulikova 1978, Crooks 1996). Unlike most mussels, M. senhousia lives entirely within the sediments, surrounded by a bag of byssal threads (Morton 1974). At mussel densities $>1500 \mathrm{~m}^{-2}$, individual byssal bags coalesce to form a continuous mat or carpet on the sediment surface (Reusch \& Williams 1999). The presence of mussel mats dramatically alters the natural benthic habitat, changing both the local physical environment and the resident macroinvertebrate assemblage (Morton 1974, Crooks 1998, Crooks \& Khim 1999). Although the creation of new habitat structure associated with high densities of mussels can result in increased species richness and abundances of some infaunal taxa (Crooks 1998, Crooks \& Khim 1999), mussel mats reduce the densities of many common native bivalves and the growth of nearby eelgrass (possibly due to spatial interference) (Crooks 1992, Reusch \& Williams 1998).

The interactions between Musculista senhousia and Zostera marina are complex, however, and in southern California M. senhousia is found at mat-forming densities only in areas where eelgrass beds are fragmented and sparsely vegetated or absent (Reusch \& Williams 1998, 1999). Where eelgrass is dense, the growth and survival of M. senhousia are poor (Reusch \& Williams 1998, 1999). Mussel growth rates are highest outside of $Z$. marina beds and decrease with increasing eelgrass patch size and distance from the edge of the leaf canopy. This inverse pattern of eelgrass versus mussel distribution and growth also correlates well with water flow speeds (Reusch \& Williams 1999), which are highest outside eelgrass beds but slow within the canopy as momentum is extracted through friction along the leaf surfaces (reviewed in Koch 2001). These observations provide a mechanism by which eelgrass could influence mussel growth and distribution. Dependent on water flow for delivery of their phytoplankton food, mussels living in dense eelgrass or deep within a large eelgrass patch might be severely food-limited as an indirect consequence of eelgrass effectively blocking water flow through its leaf canopy. The expectation that mussels within eelgrass beds have less food is supported by observations of lower concentrations of chlorophyll $a(\mathrm{chl} a)$ in the feeding ambit of mussels inside eelgrass patches compared to in nearby unvegetated areas (Reusch \& Williams 1999). Reduced water flow and local depletion of suspended particles has been implicated in food limitation of other suspensionfeeding organisms (Wildish \& Kristmanson 1984, Fréchette et al. 1989, Butman et al. 1994), and there is compelling indirect evidence that bivalve growth can be limited by food availability (Kautsky 1982, Peterson 1982, Bertness \& Grosholz 1985, Fréchette \& Bourget 1985, Peterson \& Black 1987). This hypothesis has not, however, been tested directly in the field.

For many marine invertebrates, an inevitable consequence of limited food availability is a reduction in individual growth and fecundity (reviewed in Ólafsson et al. 1994). A prediction of the hypothesis that Musculista senhousia in eelgrass are food-limited is that growth and fecundity will be reduced relative to mussels living outside Zostera marina beds. Some organisms, however, can maintain a relatively high level of fecundity even when food is limited by reallocating available resources to reproduction at the expense of growth (a trade-off) (Bayne 1976, reviewed for bivalves in Griffiths \& Griffiths 1987, Thompson \& MacDonald 1991). Populations of M. senhousia at sites in southern California are often short-lived, suggesting that the mussel is highly dependent on successful reproduction and dispersal for persistence (Crooks 1996, T. A. Ebert \& S. L. Williams unpubl. data). When resources are limited, the ability to preferentially allocate those available to the production of gametes might therefore be adaptive.

The purpose of our study was to (1) provide a direct test of whether Musculista senhousia is food-limited in Zostera marina by experimentally supplementing the phytoplankton available to mussels living in a natural eelgrass bed, (2) quantify the effects of food limitation on relative growth and fecundity of $M$. senhousia in the laboratory, and (3) compare relative growth and fecundity of $M$. senhousia inside of and outside a natural eelgrass bed. 


\section{MATERIALS AND METHODS}

Experimental manipulations were done at Silver Strand $\left(32^{\circ} 38^{\prime} 01^{\prime \prime} \mathrm{N}, 117^{\circ} 08^{\prime} 03^{\prime \prime} \mathrm{W}\right)$ and Harbor Island $\left(32^{\circ} 43^{\prime} 25^{\prime \prime} \mathrm{N}, 117^{\circ} 11^{\prime} 19^{\prime \prime} \mathrm{W}\right)$, San Diego Bay, California, USA. Both are sheltered subtidal sites with Zostera marina leaf shoot densities and heights typical of other local eelgrass beds. Musculista senhousia is commonly found at mat-forming densities in the adjacent unvegetated sand flats, although the abundance of the mussel varies considerably in space and time. All observations and experimental manipulations were accomplished by SCUBA.

In situ food addition to mussels. Mussels were collected from a sand flat adjacent to the eelgrass bed at Silver Strand in June 1998, and tagged in an aerated solution of calcein in seawater $\left(100 \mathrm{mg} \mathrm{l}^{-1}\right)$ for $24 \mathrm{~h}$. Calcein is a fluorescent dye that is incorporated into the shells of growing mussels as a marker for initial size (Wilson et al. 1987, Kaehler \& McQuaid 1999). Individual growth was measured later under a microscope with an ultraviolet epi-illuminator as the distance from the tag to the shell margin. Tagging efficiency was $100 \%$ (50/50 mussels examined), and previous work has demonstrated that there are no negative effects of tagging on growth or survival of molluscs (Kaehler \& McQuaid 1999, Moran 2000). We deliberately chose small mussels for this experiment (5 to $12 \mathrm{~mm}$ shell length; $\mathrm{n}=225$ ) because Musculista senhousia of this size range exhibit the fastest growth (T. A. Ebert \& S. L. Williams unpubl. data).

Following tagging, mussels were transplanted at mat-forming densities ( $\mathrm{n}=75$ mussels) into 24 plots $\left(100 \mathrm{~cm}^{-2}\right.$ ) within the eelgrass bed (20 to $30 \mathrm{~m}$ from the edge). All resident mussels were removed from the experimental plots prior to the beginning of the experiment. Although each plot was bounded by a buried ring of polyethylene mesh $(15 \mathrm{~cm}$ diameter; $6 \mathrm{~mm}$ mesh size) to facilitate mussel recovery at the end of the experiment, the transplanted mussels tended to remain clumped together in the middle of the plot for the duration of the experiment. Each plot was separated from the others by at least $3 \mathrm{~m}$. Eelgrass leaf shoot density was $314 \pm 23$ shoots $\mathrm{m}^{-2}$ (mean $\pm 1 \mathrm{SE}$, $\mathrm{n}=24,50 \times 50 \mathrm{~cm}$ quadrats) and leaf height was $63 \pm 5 \mathrm{~cm}$ (tallest leaf of $\mathrm{n}=5$ shoots quadrat ${ }^{-1}$ ).

Replicated plots $(n=6)$ received 1 of 4 treatments: (1) laboratory-cultured phytoplankton added to the water above the mussels, (2) unmanipulated ambient conditions, (3) culture medium but no additional phytoplankton added to the water above the mussels, and (4) the presence of a non-operating delivery system. Musculista senhousia readily consumed the phytoplankton Tetraselmis sp. $\left(10^{4}-10^{5}\right.$ cells $\left.\mathrm{ml}^{-1}\right)$ and Nannochloropsis sp. $\left(10^{5}-10^{6}\right.$ cells $\left.\mathrm{ml}^{-1}\right)$ cultured in nutrient-enriched natural seawater (Strathmann 1987) during a preliminary experiment (authors' unpubl. data). Microscopic analyses of the gut contents of mussels verified that $M$. senhousia in San Diego Bay eelgrass beds feeds primarily on small ( $\sim$ \% diameter) phytoplankton (authors' unpubl. data), rather than on benthic microalgae that might represent an important source of food to other bivalves living in seagrasses (e.g. Judge et al. 1993). Fresh culture medium \pm phytoplankton was delivered from $20 \mathrm{l}$ soft plastic containers placed close to each plot daily for $28 \mathrm{~d}$ (1 container per plot). A small weight (1.4 kg) on top of each container forced the culture medium through a flexible tube into the water column $1 \mathrm{~cm}$ above the mussels, delivering approximately $10 \mathrm{l}$ over a $6 \mathrm{~h}$ period (09:00 to 15:00 $\mathrm{h}$ daily). The flow of culture medium from storage containers to the water above experimental plots was visually inspected using fluorescein dye.

To test the efficacy of the phytoplankton treatment, food availability (concentration of chl a) above the experimental plots was measured weekly ( $\mathrm{n}=4$ sampling dates). On each sampling date, immediately prior to the addition of culture medium \pm phytoplankton and hourly for $6 \mathrm{~h}$ thereafter, duplicate seawater samples were collected at a distance of $1 \mathrm{~cm}$ above the mussels in each plot using $60 \mathrm{ml}$ syringes. Water samples were taken from the middle of each plot (approximately $10 \mathrm{~cm}$ from the phytoplankton discharge tube). Water was withdrawn at a rate of $20 \mathrm{ml} \mathrm{min} \mathrm{m}^{-1}$ to mimic active filtering by mussels (Judge et al. 1993). The samples were immediately filtered through $1.2 \mu \mathrm{m}$ mesh glassfiber filters (Watson GF/C), and extracted with $90 \%$ acetone in the dark for $24 \mathrm{~h}$. Concentrations of chl a were determined fluorometrically according to Parsons et al. (1984). Because the phytoplankton medium was fertilized with ammonium which could be harmful to molluscs, we measured ammonium concentrations in duplicate samples of water taken above each plot $1 \mathrm{~h}$ after the start of the treatments, filtering and adding reagents immediately (Koroleff 1976). Ammonium concentrations in the plots receiving culture medium \pm phytoplankton were higher than in the ambient or delivery system control plots, but the elevated concentrations of $8.9 \pm 2.4 \mu \mathrm{mol} \mathrm{l} \mathrm{l}^{-1}($ mean $\pm 1 \mathrm{SE}, \mathrm{n}=24)$ were within the natural range of values which occur locally, and well below concentrations which are harmful to other bivalves (Nalepa \& Schloesser 1993, Sewell 1996).

After $28 \mathrm{~d}$, the sediment inside each plot (to a depth of $\sim 8 \mathrm{~cm}$ ) was sieved through $1 \mathrm{~mm}$ mesh screen. Mussels were collected, preserved in $70 \%$ ethyl alcohol, and 25 individuals were randomly selected per plot. Mussel shell length and growth were measured to the nearest $0.1 \mathrm{~mm}$ with a digital caliper and ocular micrometer, and tissue mass to the nearest $0.1 \mathrm{mg}$ after 
drying until constant mass at $70^{\circ} \mathrm{C}$. Mussels were identified as experimentally transplanted by the presence of a calcein tag. Survival in each plot was estimated as the number of tagged/number of transplanted mussels.

Effects of food limitation in the laboratory. To assess the effects of food limitation on growth and reproduction of Musculista senhousia under controlled conditions in the laboratory, adult mussels (8 to $28 \mathrm{~mm}$ in length) were collected from outside the eelgrass bed at Harbor Island in June 1997 and immediately tagged with calcein. After tagging, mussels were evenly distributed across a shallow flow-through water table (length $2.5 \mathrm{~m}$, width $1.0 \mathrm{~m}$, water depth $10 \mathrm{~cm}$ ) filled with $10 \mathrm{~cm}$ of washed sand from San Diego Bay to form a dense assemblage of individuals (1650 \pm 290 ind. $\mathrm{m}^{-2}$; mean $\pm 1 \mathrm{SD}$, assessed with 20 haphazardly placed cores of $50 \mathrm{~cm}^{2}$ ). Seawater pumped directly from San Diego Bay flowed uni-directionally across the length of the experimental mussel bed (inflow of approximately $41 \mathrm{~min}^{-1}$ ). M. senhousia at this density can reduce near-bottom food resources by up to $70 \%$ compared with ambient seawater (Reusch \& Williams 1999). The experimental mussel bed provided for an assessment of mussel response along a gradient of decreasing food availability (from a maximum of ambient at the inflow pipe).

Mussels were held under conditions of ambient light and water temperature $\left(22.1\right.$ to $\left.25.2^{\circ} \mathrm{C}\right)$ for the duration of the experiment. Food availability to mussels along the length of the water table was measured weekly ( $\mathrm{n}=8$ sampling dates) as the local concentration of chl a. On each sampling date, duplicate seawater samples were collected $1 \mathrm{~cm}$ above the mussels at 0.00 , $0.75,1.50$, and $2.25 \mathrm{~m}$ downstream of the inflow pipe. On 3 sampling dates, ammonium concentration, dissolved oxygen concentration, and $\mathrm{pH}$ were also measured at the inflow and outflow pipes to assess water quality for mussel growth. Dissolved oxygen concentrations were measured using a YSI oxygen meter (Model 53), and $\mathrm{pH}$ using a Beckman $\mathrm{pH}$ meter (Model 32).

In southern California, Musculista senhousia spawns primarily in the late summer and early fall (Crooks 1996, authors' unpubl. data). Beginning in January 1997, monthly assessments of the color, texture, and thickness of mantle tissues from the Harbor Island mussel population were made to ensure the experiment began prior to significant gametogenesis. Like other mytilid mussels (Seed \& Suchanek 1992), the gonad of $M$. senhousia is typically orange in females and white in males, while the mantle tissues of nonreproductive mussels are relatively thin and transparent. With the exception of a few hermaphrodites, M. senhousia populations in southern California have approximately equal numbers of males and females (authors' unpubl. data).
The reproductive status of mussels $(n=20)$ was assessed weekly so that the experiment could be ended before the mussels spawned. After $54 \mathrm{~d}$, mussels were collected from the water table at $0.00,0.75,1.50$, and $2.25 \mathrm{~m}$ from the inflow pipe, using haphazardly placed cores of $50 \mathrm{~cm}^{2}$ ( $\mathrm{n}=6$ cores location $\left.{ }^{-1}\right)$. Shell length and growth, and gonad and somatic tissue dry mass of 30 randomly selected mussels per location were measured. To assess relative fecundity, a gonad index was calculated for each mussel as the ratio of gonad dry mass to total tissue dry mass (the sexes were not considered separately, as gonad index values were similar for male and female mussels).

Effects of an eelgrass bed. To assess the effects of an eelgrass bed on the growth and reproduction of Musculista senhousia, a field experiment was conducted concurrently with the laboratory food limitation experiment. Tagged mussels from the same Harbor Island collection ( $\mathrm{n}=50$ mussels $100 \mathrm{~cm}^{-2}$ ) were transplanted into 12 plots inside the dense eelgrass bed at Harbor Island (5 to $10 \mathrm{~m}$ from the edge), and 12 plots in the adjacent unvegetated sand flat. All resident mussels were removed before introduction of the tagged mussels. Plots were bounded by a buried ring of polyethylene mesh, and were separated by at least $3 \mathrm{~m}$. Half of the plots in each location $(n=6)$ were caged to protect the mussels from predators. Predation on M. senhousia in San Diego Bay is variable among sites and habitats, but mussel mortality due to predation (primarily by the muricid snail Pteropurpura festiva) can be high at times in the eelgrass bed at Harbor Island (Reusch 1998, Reusch \& Williams 1998). Cages were circular (diameter = $20 \mathrm{~cm})$, constructed of polyethylene mesh $(11 \mathrm{~mm}$ mesh size), and buried in the sediments to a depth of $8 \mathrm{~cm}$. Each cage extended $15 \mathrm{~cm}$ into the water column, and had a conical roof to shed eelgrass litter. Previous studies have demonstrated that experimental artifacts of this type of cage on $M$. senhousia growth at this site are minimal (Reusch 1998, Reusch \& Williams 1999). Plots were checked weekly for $P$. festiva, and snails found feeding in the experimental plots were counted and removed.

Eelgrass leaf shoot density was $232 \pm 41$ shoots $\mathrm{m}^{-2}$ (mean $\pm 1 \mathrm{SE}, \mathrm{n}=12,50 \times 50 \mathrm{~cm}$ quadrats), and leaf height was $76 \pm 8 \mathrm{~cm}$ (tallest leaf of $\mathrm{n}=5$ shoots quadrat $^{-1}$ ). After $54 \mathrm{~d}$, the sediment inside each plot was sieved, and the surviving mussels preserved in alcohol. Shell growth and tissue mass were measured for 20 randomly chosen mussels per plot, and a gonad index calculated as in the laboratory experiment. Mussel survival per plot was calculated as in the in situ food addition experiment.

Statistical analyses. Chl a concentrations were compared among treatments (fixed) and sampling times 
(random) using 2-way mixed model analysis of variance (ANOVA). Mussel shell growth and tissue mass are functions of individual size. Consequently, mean shell growth among treatments (fixed) was compared using analysis of covariance (ANCOVA), with initial shell length as the covariate, and plots (random, nested within treatment) as the error component (Sokal \& Rohlf 1995). Differences in mean mussel tissue mass were evaluated using ANCOVA with final shell length as the covariate. Mean values of the gonad index and survival were compared among treatments using ANOVA with plots (random, nested within treatment) as the error component.

Visual inspection of model residuals was done for every analysis. Where variances showed significant heterogeneity, the data were transformed using a $\ln (x+1)$ function. Gonad index and survival data were transformed using an arcsine $(\sqrt{x})$ function to meet distributional assumptions of normality (Sokal \& Rohlf 1995). Following ANOVA or ANCOVA, Tukey's HSD tests were used to identify significant differences among appropriate means.

\section{RESULTS}

\section{In situ food addition to mussels}

Food availability in the experimental plots was 3 to 4 times higher than in the ambient and control plots following the addition of phytoplankton (Fig. 1). Despite significant temporal variation, the direction and magnitude of these differences were comparable on all 4 sampling dates, as evidenced by a non-significant treatment $\times$ sampling date interaction (Table 1). Chl a concentrations in the ambient plots were consistent with other measurements taken in San Diego Bay during summer months (Reusch \& Williams 1999, authors' unpubl. data). Fluorescein-dyed medium flowed from the storage containers to the water directly overlying the mussels and remained there as a discernable water mass ( $30 \mathrm{~cm}$ diameter) for at least $6 \mathrm{~h}$.

Mussels given supplemental phytoplankton grew $40 \%$ more than mussels under ambient conditions (Fig. 2A) supporting the hypothesis that food is a limiting resource for Musculista senhousia in eelgrass. In addition to the statistically significant treatment effect, there was also a significant plot effect for mussel shell growth ( $p=0.024$, Table 1$)$. This is due entirely to variability among plots within the plankton addition treatment, presumably because the efficacy of our treatment application (although successful overall) was variable among plots. Although mussels in the food addition treatment were larger at the end of the experiment, mean dry tissue mass of individu-

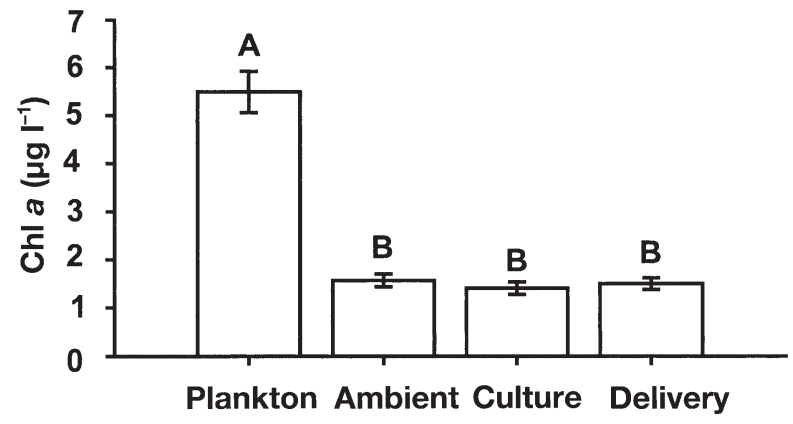

Fig. 1. Chl a concentrations (mean $\pm \mathrm{SE}, \mathrm{n}=24$ ) among treatments in the in situ food addition experiment in the eelgrass bed at Silver Strand, San Diego Bay. Water samples were taken $1 \mathrm{~cm}$ above mussels Musculista senhousia in each plot. Data were pooled over 4 sampling dates because the interaction treatment $\times$ sampling date was not significant (Table 1 ; Winer et al. 1991). Differing letters indicate significant differences among treatments $(p<0.05$, Tukey's HSD multiplecomparison method)

als did not differ among treatments when adjusted for differences in final size (Table 1, Fig. 2B). This suggests that the increased shell growth of mussels in the plankton addition plots cannot be explained by the utilization of stored energy reserves. Survival was high in all plots (79 to $100 \%$ tagged mussel recovery) and did not differ among treatments (ANOVA, $F_{3,20}=$ $1.28, \mathrm{p}=0.308)$.

Table 1. Analyses of effects of treatments (plankton addition, and ambient, culture medium and delivery system controls) on chl a concentration (ANOVA), and mussel Musculista senhousia shell growth and dry tissue mass (ANCOVA) in the in situ food addition experiment. Adjusted plot means for shell growth and dry tissue mass were used to test for effects of treatments. Data were transformed using a $\ln (x+1)$ function to remove variance heterogeneity ( $\mathrm{chl} a$, shell length and tissue mass). Assumption of homogeneity of slopes was tested prior to ANCOVAs

\begin{tabular}{|c|c|c|c|c|}
\hline Source & df & MS & $F$ & $\mathrm{p}$ \\
\hline \multicolumn{5}{|l|}{ Chl a concentration } \\
\hline Treatment & 3 & 5.166 & 77.10 & $<0.001$ \\
\hline Sampling date & 3 & 0.435 & 5.95 & 0.001 \\
\hline Treatment $\times$ sampling date & 9 & 0.067 & 0.92 & 0.510 \\
\hline Error & 80 & 0.073 & & \\
\hline \multicolumn{5}{|l|}{ Shell growth } \\
\hline Treatment & 3 & 2.163 & 19.48 & $<0.001$ \\
\hline Initial shell length & 1 & 1.155 & 18.13 & $<0.001$ \\
\hline Plot (treatment) & 20 & 0.111 & 1.74 & 0.024 \\
\hline Error & 575 & 0.064 & & \\
\hline \multicolumn{5}{|l|}{ Dry tissue mass } \\
\hline Treatment & 3 & 0.022 & 1.35 & 0.286 \\
\hline Final shell length & 1 & 69.596 & 2425.37 & $<0.001$ \\
\hline Plot (treatment) & 20 & 0.016 & 0.55 & 0.945 \\
\hline Error & 575 & 0.029 & & \\
\hline
\end{tabular}



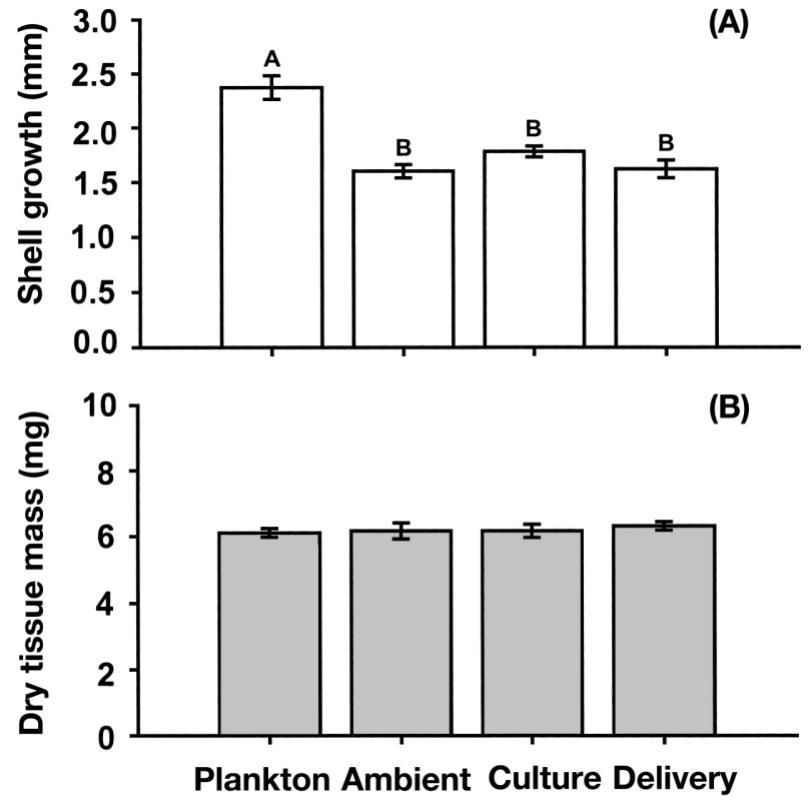

Fig. 2. Musculista senhousia. Shell growth (A, white bars) and dry tissue mass (B, gray bars) of mussels among treatments in the in situ food addition experiment in the eelgrass bed at Silver Strand, San Diego Bay (adjusted mean $\pm \mathrm{SE}, \mathrm{n}=6$ plots). Differing letters indicate significant differences among treatments $(\mathrm{p}<0.05$, Tukey's HSD multiple-comparison method)

\section{Effects of food limitation in the laboratory}

Food availability across the length of the experimental mussel bed declined monotonically with increasing distance from the inflow pipe (Fig. 3). The reduction in chl a concentrations from the inflow pipe to the $0.75 \mathrm{~m}$ sampling location ( 25\%) was comparable to the reduction in chl a concentrations measured inside ( 1 $\mathrm{m}$ from edge) versus outside eelgrass beds in San Diego Bay (Reusch \& Williams 1999). No other measures of water quality differed significantly between inflow and outflow pipes (all p > 0.210).

Mussel shell growth was correlated with chl a concentrations, also decreasing with increasing distance downstream of the inflow pipe (Table 2, Fig. 4A). The downstream reduction in shell growth across the mussel bed was mirrored by a reduction in mean dry tissue mass (adjusted for differences in final mussel size) (Table 2, Fig. 4B), suggesting that mussels farther downstream were possibly using stored energy reserves to a greater degree than those near the inflow pipe (under ambient levels of food availability). The observation that mussels with access to the least amount of food continued to increase in shell length (although at a much reduced rate) despite losing a significant proportion of soft tissue mass has been seen in other marine mussels, and may be due to the relative energetic costs of production of shell versus other tissues (Hawkins \& Bayne 1992).

Mean gonad index (gonad dry mass/total tissue dry mass) was $\sim 0.43$ for mussels at the 2 upstream locations, and $\sim 0.08$ for mussels farther downstream (Fig. 4C). Among mussels that produced gonad, variation in individual size explained very little of the variation in gonad index values $\left(\mathrm{R}^{2}=0.01\right)$. There appears to be a threshold of food availability below which little or no gonad is produced, a result that has been found in other studies of bivalve reproduction (Bayne et al. 1982, Newell et al. 1982). The importance of this threshold to Musculista senhousia in southern California may be limited, however, as mussels at multiple sites are generally observed to produce gonad (authors' unpubl. data).

\section{Effects of an eelgrass bed}

Mussels living inside dense eelgrass canopy exhibited growth and reproductive responses similar to those of food-limited mussels in the experimental mussel bed. Shell growth of individuals inside the eelgrass bed was reduced by $50 \%$ relative to mussels in the adjacent unvegetated sand flat (Table 3, Fig. 5A). As predicted, cage effects were small relative to treatment effects, and were not statistically significant (maximum of $9 \%$ different, all $\mathrm{p} \geq 0.148$ ). More importantly, the interaction between caging and habitat was also not significant (all $\mathrm{p} \geq 0.533$ ), suggesting that cage effects were similar in the eelgrass bed and the sand flat. Survival was high in all caged plots (74 to $92 \%$ tagged mussel recovery) and did not differ between habitats

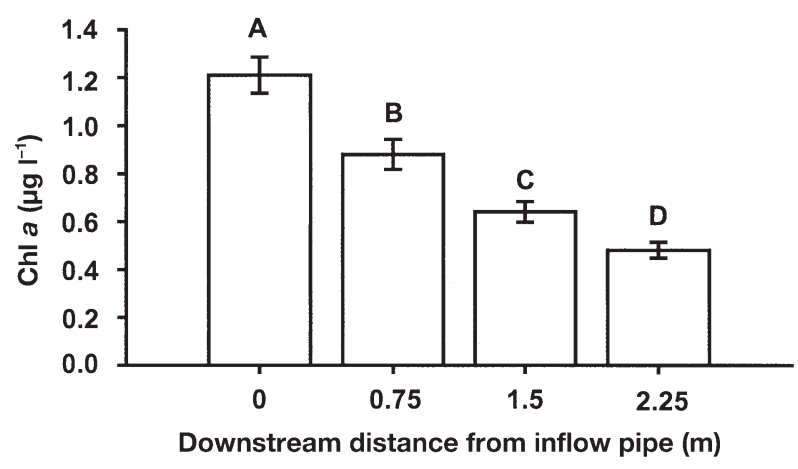

Fig. 3. Chl a concentrations (mean $\pm \mathrm{SE}, \mathrm{n}=16$ ) downstream of the water table inflow of the laboratory mussel bed experiment. Data were pooled over 8 sampling dates because the interaction treatment $\times$ sampling date was not significant (Table 3; Winer et al. 1991). Differing letters indicate significant differences among treatments $(\mathrm{p}<0.05$, Tukey's HSD multiple-comparison method) 
Table 2. Analyses of effects of downstream distance $(0.00$, $0.75,1.50$, and $2.25 \mathrm{~m}$ ) on chl a concentration (ANOVA), mussel Musculista senhousia shell growth and dry tissue mass (ANCOVA) and mussel gonad index (ANOVA) in the laboratory mussel bed experiment. Data were transformed with a $\ln (x+1)$ function to remove variance heterogeneity (chl $a_{\text {, }}$ shell length and tissue mass), and an $\operatorname{arcsine}(\sqrt{x})$ function to meet assumptions of normality (gonad index). Assumption of homogeneity of slopes was tested prior to ANCOVAs

\begin{tabular}{|lrrrc|}
\hline Source & df & MS & \multicolumn{1}{c|}{$F$} & $\mathrm{p}$ \\
\hline Chl a concentration & & & & \\
Treatment & 3 & 0.474 & 59.27 & $<0.001$ \\
Sampling date & 7 & 0.052 & 6.74 & $<0.001$ \\
Treatment $\times$ sampling date & 21 & 0.008 & 1.01 & 0.483 \\
Error & 32 & 0.008 & & \\
Shell growth & & & & \\
Treatment & 3 & 4.424 & 39.60 & $<0.001$ \\
Initial shell length & 1 & 4.992 & 44.69 & $<0.001$ \\
Error & 115 & 0.112 & & \\
Dry tissue mass & & & & \\
Treatment & 3 & 2.905 & 146.15 & $<0.001$ \\
Final shell length & 1 & 31.719 & 1595.68 & $<0.001$ \\
Error & 115 & 0.020 & & \\
Gonad index & & & & \\
Treatment & 3 & 11018.060 & 86.20 & $<0.001$ \\
Error & 116 & 127.814 & & \\
\hline
\end{tabular}

(ANOVA, $F_{1,10}=2.278, \mathrm{p}=0.162$ ). Although predation mortality was higher in the uncaged plots (particularly in the eelgrass bed), with the exception of 1 plot, mortality never exceeded $60 \%$. In contrast to other studies at this site (e.g. Reusch 1998), few Pteropurpura festiva were found feeding in experimental plots during the course of the experiment. There is no evidence that non-lethal interference by predators affects Musculista senhousia growth in San Diego Bay, and manipulative experiments have shown that mussels will continue to feed even as nearby individuals are eaten by snails (Reusch 1998, Reusch \& Williams 1998). This experiment (like the in situ food addition experiment) was probably too short to detect any effects of Zostera marina (not due to predation) on mussel survival (Reusch \& Williams 1999). Studies of longer duration have documented significantly reduced survival of $M$. senhousia inside eelgrass beds relative to unvegetated habitat in San Diego Bay (Reusch \& Williams 1998, 1999).

Like shell growth, the size-specific mean dry tissue mass of mussels in the eelgrass bed was significantly reduced compared to individuals from the sand flat (Fig. 5B). Mean gonad index, however, was similar in both treatments (Fig. 5C). As in the laboratory experiment, gonad index values were not related to mussel size $\left(R^{2}=0.05\right)$.

\section{DISCUSSION}

Our demonstration that the non-native mussel Musculista senhousia is limited by the availability of its phytoplankton food provides 1 mechanism for the resistance of dense continuous eelgrass beds to the formation of mussel mats, and the deleterious effects of such mats on eelgrass (Reusch \& Williams 1998, 1999). This result is accordant with those of other experimental manipulations showing that growth and survival of $M$. senhousia are consistently reduced inside eelgrass beds across a variety of spatial and temporal scales in southern California (Reusch \& Williams 1998, 1999). Water flow speeds are slower inside eelgrass beds than in adjacent unvegetated areas (Reusch \& Williams 1999), presumably reducing the flux of food particles to resident mussels and increasing the likelihood that the
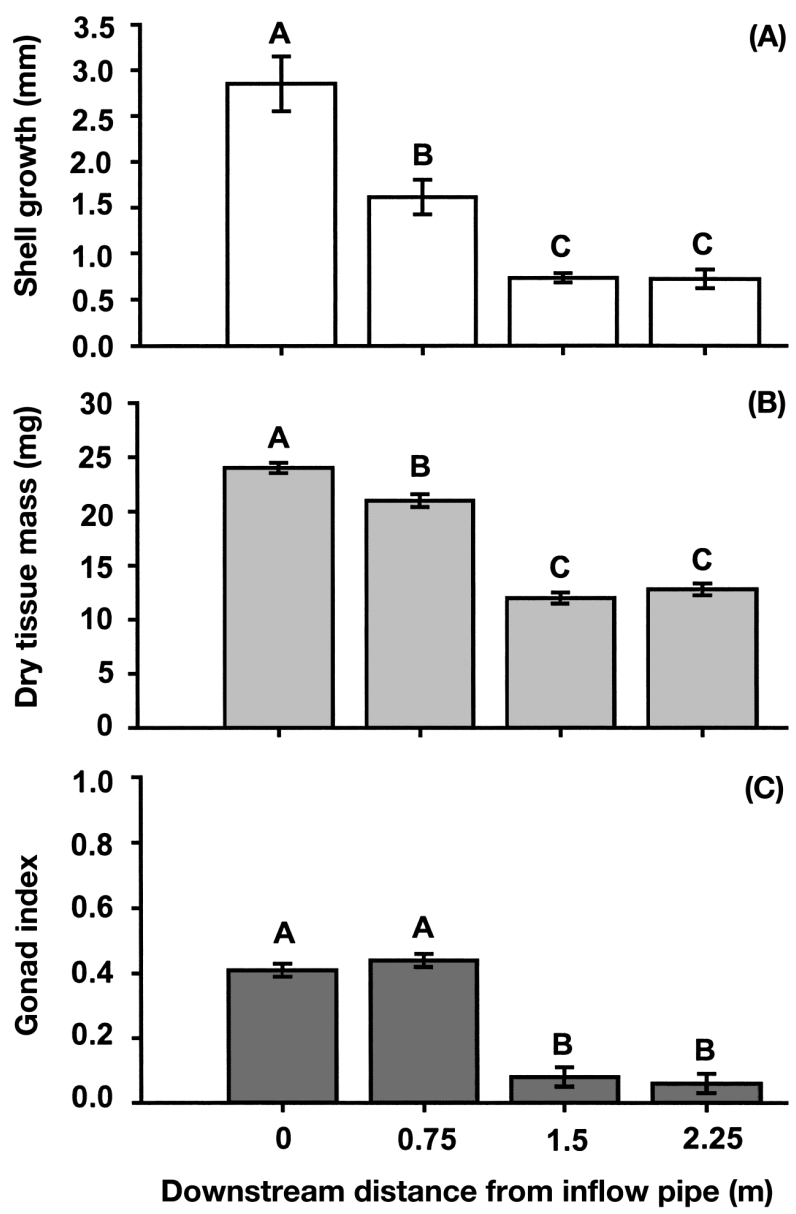

Fig. 4. Musculista senhousia. Shell growth (A, white bars) and dry tissue mass (B, light gray bars), and gonad index ( $\mathrm{C}$, dark gray bars) of mussels downstream of the water table inflow of the laboratory mussel bed experiment (A\&B: adjusted means $\pm \mathrm{SE}$; $\mathrm{C}$ : means $\pm \mathrm{SE} ; \mathrm{n}=30$ ). Differing letters indicate significant differences among treatments $(p<0.05$, Tukey's HSD multiple-comparison method) 
Table 3. Analyses of effects of habitat (Zostera marina bed vs sandflat) on mussel Musculista senhousia shell growth and dry tissue mass (ANCOVA), and mussel gonad index (ANOVA) in the Harbor Island transplantation experiment. Adjusted plot means for shell growth and dry tissue mass were used to test for effects of habitat. Data were transformed with a $\ln (x+1)$ function to remove variance heterogeneity (shell length and tissue mass), and an $\operatorname{arcsine}(\sqrt{x})$ function to meet assumptions of normality (gonad index). Assumption of homogeneity of slopes was tested prior to ANCOVAs

\begin{tabular}{|lrrrr|}
\hline Source & df & \multicolumn{1}{c}{ MS } & \multicolumn{1}{c|}{$F$} & $\mathrm{p}$ \\
\hline Shell growth & & & & \\
Treatment & 1 & 25.205 & 381.89 & $<0.001$ \\
Initial shell length & 1 & 46.824 & 479.92 & $<0.001$ \\
Plot (treatment) & 22 & 0.066 & 0.68 & 0.861 \\
Error & 454 & 0.098 & & \\
Dry tissue mass & & & & \\
Treatment & 1 & 3.292 & 205.78 & $<0.001$ \\
Final shell length & 1 & 143.320 & 5857.59 & $<0.001$ \\
Plot (treatment) & 22 & 0.016 & 0.67 & 0.869 \\
Error & 454 & 0.024 & & \\
Gonad index & & & & \\
Treatment & 1 & 30.046 & 1.52 & 0.231 \\
Plot (treatment) & 22 & 19.815 & 0.93 & 0.551 \\
Error & 455 & 21.243 & & \\
\hline
\end{tabular}

near-bottom water will be depleted of food when mussel densities are high (Wildish \& Kristmanson 1984, Fréchette et al. 1989, Butman et al. 1994).

Fecundity is highly correlated with individual size in bivalves, such that marked reductions in shell growth (as observed in our study) will result in substantial decreases in fecundity unless offset by a reallocation of resources. Our results show that Musculista senhousia responds to moderate reductions in food availability by reducing shell growth, but continues to allocate a constant proportion of resources to reproduction. There is no evidence of a trade-off in favor of reproduction when food is limited. $M$. senhousia has a very short life span of only 1 to 2 yr, and many individuals reproduce only once (Morton 1974, Crooks 1996). Mussels may consequently always be allocating the maximum possible amount of resources to reproduction, regardless of local environmental conditions. Such an expectation is consistent with predictions of life history theory for semelparous organisms (Stearns 1992). If M. senhousia reproduce only once, reductions in fecundity such as those we observed can be related directly to reductions in mussel fitness and possibly population growth.

The fact that Musculista senhousia in southern California is food-limited carries a significant implication for local eelgrass populations. Any increase in phytoplankton food supply to $M$. senhousia is likely to increase the population growth rate of the mussel, magnifying negative effects of the mussel on eelgrass.
Phytoplankton blooms resulting from nitrogen loading and subsequent eutrophication of estuaries are increasingly common (Paerl 1997, Cloern 2001), and could release $M$. senhousia from food limitation. Such blooms also directly affect Zostera marina by reducing the transmittance of light critical for eelgrass growth and distribution (Dennison \& Alberte 1985, Zimmerman et al. 1991, Moore et al. 1996, Bricelj \& Lonsdale 1997), and have been implicated in numerous seagrass declines around the world (Dennison et al. 1993, Short \& Wyllie-Echeverria 1996, Paerl 1997). Increases in the frequency and duration of blooms in southern California could act synergistically with $M$. senhousia to com-
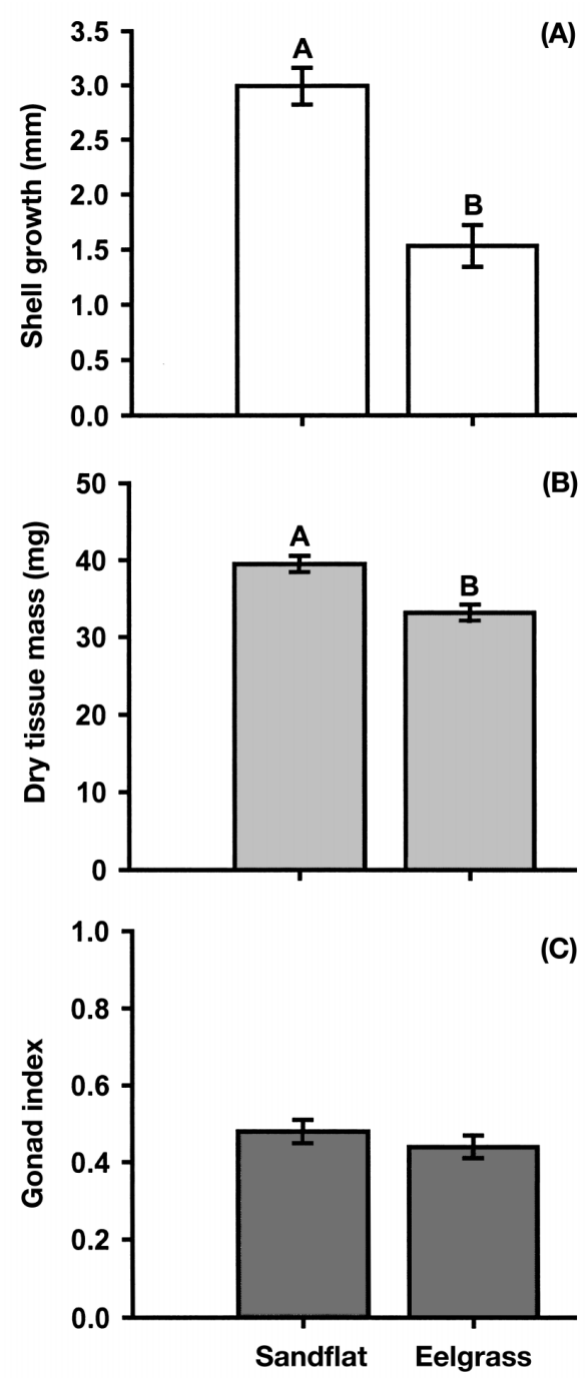

Fig. 5. Musculista senhousia. Shell growth (A, white bars) and dry tissue mass (B, light gray bars), and gonad index (C, dark gray bars) of mussels in the eelgrass bed and adjacent unvegetated sand flat at Harbor Island, San Diego Bay (A \& B: adjusted means $\pm \mathrm{SE}$; $\mathrm{C}$ : means $\pm \mathrm{SE}_{i} \mathrm{n}=6$ plots). Differing letters indicate significant differences among treatments $(\mathrm{p}<$ 0.05, Tukey's HSD multiple-comparison method) 
promise eelgrass populations in the region. Although increases in water clarity associated with the introduction of bivalves (e.g. Dreissena polymorpha and Potamocorbula amurensis) into other systems have been demonstrated or hypothesized (Alpine \& Cloern 1992, Padilla et al. 1996, Karatayev et al. 1997), there are no historical data to assess whether M. senhousia has had a similar effect. Nevertheless, given the observation that mussel mats apparently interfere spatially with rhizome extension by eelgrass, it is hard to imagine that the net effect of mussels on eelgrass population growth will be positive even if they do increase water clarity through their filtration activities.

The consistent negative effects of Musculista senhousia on asexual propagation of eelgrass in southern California are undoubtedly exacerbated by eelgrass decline due to other factors, which include sedimentation due to storm water runoff, heat stress in summer and interactions with other marine organisms (Sewell 1996, Williams 2001). Fragmentation of eelgrass beds through human activities such as boating, dredging, marine construction, and subsequent mitigation activities also favors M. senhousia over Zostera marina in several ways. Growth and abundance of the mussel are negatively correlated with eelgrass patch size, so reductions in patch size should result in better conditions for the mussel. M. senhousia also recruits into open space much more readily than eelgrass. The short life span ( 1 to 2 yr) and planktonic larval stage of $M$. senhousia effectively uncouples mussel population persistence from local environmental conditions. In an extreme example, populations in frequently disturbed areas could be maintained entirely by the recruitment of mussels from other locations. In contrast, eelgrass relies primarily upon the vegetative growth of nearby plants for recolonization (Thayer et al. 1984). Seeds of $Z$. marina rarely disperse more than a few centimeters to meters (Orth et al. 1994), and successful reestablishment of vegetative fragments is uncommon (Ewanchuk \& Williams 1996). Without nearby established patches, eelgrass is unlikely to recover even in areas previously vegetated (Thayer et al. 1984).

Reduced growth of bivalves in seagrass beds is not necessarily a general phenomenon, and the direction of the growth response depends on factors linked to water flow (e.g. eelgrass patch size and leaf shoot density), local production and resuspension of benthic microalgae, bivalve density, and in some cases disturbance of bivalve feeding by predators (reviewed in Williams \& Heck 2001). Although our results are currently limited to eelgrass beds similar to those in southern California, identification of the mechanism underlying poor growth and hypothetically survival of Musculista senhousia in these beds should foster increased attention to the ecological effects of multiple disturbances to eelgrass, including but not limited to non-native species, eutrophication and increasing algal blooms, and population fragmentation. On the Pacific coast of the USA $M$. senhousia is now common from San Diego north to British Columbia (Carlton 1992), and its global distribution overlaps extensively with that of Zostera marina and other seagrasses, including Europe, Asia, and Australia and New Zealand in addition to North America (den Hartog 1970, Crooks 1996).

Ecologically significant changes resulting from multiple perturbations acting in combination, synergistically, or occurring at a rate faster than that of ecosystem recovery are occurring in other estuaries (NRC 1995, Paine et al. 1998). For example, the invasion of San Francisco Bay, California, by the Asian clam Potamocorbula amurensis was apparently facilitated by extreme climatic events that displaced the resident benthic community long enough for $P$. amurensis to establish successfully (Carlton et al. 1990, Nichols et al. 1990). The invasive clam has persisted in spite of the return of normal environmental conditions, and has dramatically altered the trophic webs and community structure in the estuary (Alpine \& Cloern 1992, Kimmerer et al. 1994). In San Diego Bay, we have observed mussel mats covering large areas of the substratum otherwise suitable as eelgrass habitat, and it is conceivable that the ecological perturbations described above could promote a transition from eelgrass beds to mats of Musculista senhousia (Peterson et al. 1987). Replacement of eelgrass with mussels would have dramatic and long-lasting effects on the structure and function of the local estuarine ecosystem. Benthic primary production would decrease, as would the abundances of common native bivalves and eelgrass-dependent species such as the California halibut and the brant goose (Kramer 1991, Crooks 1998, Reusch \& Williams 1998, Crooks \& Khim 1999, Valle et al. 1999). As with P. amurensis in San Francisco Bay, and the zebra mussel Dreissena polymorpha in the Hudson River, New York (Baker et al. 1998), large numbers of actively filtering $M$. senhousia also have the potential to alter the abundance and distribution of the local plankton assemblage. The future management and conservation of ecologically valuable estuarine resources such as $Z$. marina requires a greater understanding of how multiple perturbations interact, and the relative importance of direct versus indirect effects (Menge 1997). Given the demonstrated negative effects of $M$. senhousia on eelgrass in southern California (Reusch \& Williams 1998), our study clearly points out that preventing further eelgrass habitat fragmentation and developing and enforcing water quality standards will be critical not just in and of themselves, but also because they could mitigate effects of this non-native mussel on native seagrass. 
Acknowledgements. We thank T. B. H. Reusch, J. Sibley, and M. R. Johnson for help in the field, and T. A. Ebert for many thoughtful discussions. This project was funded in part by grants to B.J.A. from the national and San Diego chapters of Sigma-Xi, and the American Museum of Natural History, Lerner-Gray Fund for Marine Research, and also by grants to S.L.W. from the National Sea Grant College Program (T. A. Ebert, co-PI) under grant no. NA66RG0477 and the Coastal Ocean Program under grant no. NA36RGO469, National Oceanic and Atmospheric Administration (NOAA), US Department of Commerce, both through the California Sea Grant College System. The views expressed herein are those of the authors and do not necessarily reflect the views of NOAA or any of its sub-agencies. The US Government is authorized to reproduce and distribute this article for governmental purposes. This is Contribution 2178 from the Bodega Marine Laboratory, University of California at Davis.

\section{LITERATURE CITED}

Alpine AE, Cloern JE (1992) Trophic interactions and direct physical effects control phytoplankton biomass and production in an estuary. Limnol Oceanogr 37:946-955

Baker SM, Levinton JS, Kurdeziel JP, Shumway SE (1998) Selective feeding and biodeposition by zebra mussels and their relation to changes in phytoplankton composition and seston load. J Shell Res 17:1207-1213

Bayne BL (1976) Aspects of reproduction in bivalve mollusks. In: Wiley M (ed) Estuarine processes, Vol 1. Uses, stresses, and adaptations to the estuary. Academic Press, New York, p 432-448

Bayne BL, Bubel A, Gabbott PA, Livingstone DR, Lowe DM, Moore MN (1982) Glycogen utilization and gametogenesis in Mytilus edulis L. Mar Biol Lett 3:89-105

Benson WH (1842) Mollusca. In: Cantor $\mathrm{T}$ (ed) General features of Chusan with remarks on the flora and fauna of that island. Ann Mag Nat Hist 9:481-493

Bertness MD, Grosholz E (1985) Population dynamics of the ribbed mussel, Geukensia demissa: the costs and benefits of an aggregated distribution. Oecologia 67:192-204

Bricelj VM, Lonsdale DJ (1997) Aureococcus anophagefferens: causes and ecological consequences of brown tides in US mid-Atlantic coastal waters. Limnol Oceanogr 42: 1023-1038

Butman CA, Fréchette M, Geyer WR, Starczak VR (1994) Flume experiments on food supply to the blue mussel Mytilus edulis L. as a function of boundary-layer flow. Limnol Oceanogr 39:1755-1768

Carlton JT (1992) Introduced marine and estuarine mollusks of North America: an end-of-the-20th-century perspective. J Shell Res 11:489-505

Carlton JT, Thompson JK, Schemel LE, Nichols FH (1990) Remarkable invasion of San Francisco Bay (California, USA) by the Asian clam Potamocorbula amurensis. I. Introduction and dispersal. Mar Ecol Prog Ser 66:81-94

Cloern JE (2001) Our evolving conceptual model of the coastal eutrophication problem. Mar Ecol Prog Ser 210:223-253

Crooks JA (1992) The ecology of the introduced bivalve, Musculista senhousia, in Mission Bay, San Diego. MS thesis, San Diego State University, San Diego

Crooks JA (1996) The population ecology of an exotic mussel, Musculista senhousia, in a southern California bay. Estuaries 19:42-50

Crooks JA (1998) Habitat alteration and community-level effects of an exotic mussel, Musculista senhousia. Mar Ecol Prog Ser 162:137-152
Crooks JA, Khim HS (1999) Architectural vs biological effects of a habitat-altering, exotic mussel, Musculista senhousia. J Exp Mar Biol Ecol 240:53-75

den Hartog C (1970) Seagrasses of the world. North-Holland, Amsterdam

Dennison WC, Alberte RS (1985) Role of daily light period in the depth distribution of Zostera marina (eelgrass). Mar Ecol Prog Ser 25:51-61

Dennison WC, Orth RJ, Moore KA, Stevenson JC, Carter V, Kollar S, Bergstrom PW, Batuik RA (1993) Assessing water quality with submerged aquatic vegetation. Bioscience 43: 86-94

Ewanchuk PJ (1995) Population growth in eelgrass (Zostera marina L.): the relative importance of sexual versus asexual reproduction. MS thesis, San Diego State University, San Diego

Ewanchuk PJ, Williams SL (1996) Survival and re-establishment of vegetative fragments of eelgrass (Zostera marina). Can J Bot 74:1584-1590

Fréchette M, Bourget E (1985) Energy flow between the pelagic and benthic zones: factors controlling particulate organic matter available to an intertidal mussel bed. Can J Fish Aquat Sci 42:1158-1165

Fréchette M, Butman CA, Geyer WR (1989) The importance of boundary-layer flows in supplying phytoplankton to the benthic suspension feeder, Mytilus edulis L. Limnol Oceanogr 34:19-36

Griffiths CL, Griffiths RJ (1987) Bivalvia. In: Pandian TJ, Vernberg FJ (eds) Animal energetics, Vol 2. Bivalvia through Reptilia. Academic Press, New York, p 1-88

Hauxwell J, Cebrian J, Furlong C, Valiela I (2001) Macroalgal canopies contribute to eelgrass (Zostera marina) decline in temperate estuarine ecosystems. Ecology 82:1007-1022

Hawkins AJS, Bayne BL (1992) Physiological interrelations, and the regulation of production. In: Gosling $\mathrm{E}$ (ed) The mussel Mytilus: ecology, physiology, genetics and culture. Elsevier Science Publishers, Amsterdam, p 171-222

Judge ML, Coen LD, Heck KL Jr (1993) Does Mercenaria mercenaria encounter elevated food levels in seagrass beds? Results from a novel technique to collect suspended food resources. Mar Ecol Prog Ser 92:141-150

Kaehler S, McQuaid CD (1999) Use of the fluorochrome calcein as an in situ growth marker for the brown mussel Perna perna. Mar Biol 133:455-460

Karatayev AY, Burlakova LE, Padilla DK (1997) The effects of Dreissena polymorpha (Pallas) invasion on aquatic communities in eastern Europe. J Shell Res 16:187-203

Kautsky N (1982) Growth and size structure in a Baltic Mytilus edulis population. Mar Biol 68:117-133

Kimmerer WJ, Gartside E, Orsi JJ (1994) Predation by an introduced clam as the likely cause of substantial declines in zooplankton of San Francisco Bay. Mar Ecol Prog Ser 113:81-93

Koch EW (2001) Beyond light: physical, geological, and geochemical parameters as possible submersed aquatic vegetation habitat requirements. Estuaries 24:1-17

Koroleff $\mathrm{F}$ (1976) Determination of $\mathrm{NH}_{4}{ }^{+}-\mathrm{N}$. In: Grasshoff $\mathrm{K}$ (ed) Methods of seawater analysis. Verlag Chemie, Weinheim, p 127-133

Kramer SH (1991) Growth, mortality, and movements of juvenile California halibut, Paralichthys californicus, in shallow coastal and bay habitats of San Diego County, California. Fish Bull 89:195-207

Kulikova VA (1978) Morphology, seasonal population dynamics, and settlement of larvae of the bivalve mollusc Musculista senhousia in Busse Lagoon (South Sakhalin). Biologiya Morya 4:769-773; in Russian (translation [1979] Soviet J Mar Biol 4:769-773) 
MacDonald KB (1969) Quantitative studies of salt marsh mollusc faunas from the North American Pacific coast. Ecol Monogr 39:33-59

McRoy CP, Helfferich C (1977) Seagrass ecosystems: a scientific perspective. Marcel Dekker, New York

Menge BA (1997) Detection of direct versus indirect effects: were experiments long enough? Am Nat 149:801-823

Moore KA, Neckles HA, Orth RJ (1996) Zostera marina (eelgrass) growth and survival along a gradient of nutrients and turbidity in the lower Chesapeake Bay. Mar Ecol Prog Ser 142:247-259

Moran AL (2000) Calcein as a marker in experimental studies of newly-hatched gastropods. Mar Biol 137:893-898

Morton B (1974) Some aspects of the biology, population dynamics, and functional morphology of Musculista senhousia Benson (Bivalvia, Mytilidae). Pac Sci 28:19-33

Nalepa TF, Schloesser DW (1993) Zebra mussels: biology, impacts, and control. Lewis Publishers, Boca Raton, FL

National Research Council (1995) Understanding marine biodiversity: a research agenda for the nation. National Academy Press, Washington, DC

Newell RIE, Hilbish TJ, Koehn RK, Newell CJ (1982) Temporal variation in the reproductive cycle of Mytilus edulis L. (Bivalvia, Mytilidae) from localities on the east coast of the United States. Biol Bull 162:299-310

Nichols FH, Thompson JK, Schemel LE (1990) Remarkable invasion of San Francisco Bay (California, USA) by the Asian clam Potamocorbula amurensis. II. Displacement of a former community. Mar Ecol Prog Ser 66:95-101

Ólafsson EB, Peterson CH, Ambrose WG Jr (1994) Does recruitment limitation structure populations and communities of macro-invertebrates in marine soft sediments: the relative significance of pre- and post-settlement processes. Oceanogr Mar Biol Annu Rev 32:65-109

Orth RJ, Luckenbach M, Moore KA (1994) Seed dispersal in a marine macrophyte: implications for colonization and restoration. Ecology 75:1927-1939

Padilla DK, Adolph SC, Cottingham KL, Schneider DW (1996) Predicting the consequences of dreissenid mussels on a pelagic food web. Ecol Model 85:129-144

Paerl HW (1997) Coastal eutrophication and harmful algal blooms: importance of atmospheric deposition and groundwater as 'new' nitrogen and other nutrient sources. Limnol Oceanogr 42:1154-1165

Paine RT, Tegner MJ, Johnson EA (1998) Compounded perturbations yield ecological surprises. Ecosystems 1: 535-545

Parsons TR, Maita Y, Lalli CM (1984) A manual of chemical and biological methods for seawater analysis. Pergamon Press, Oxford

Peterson CH (1982) The importance of predation and intraand interspecific competition in the population biology of two infaunal suspension-feeding bivalves, Protothaca staminea and Chione undatella. Ecol Monogr 52:437-475

Peterson CH, Black R (1987) Resource depletion by active suspension feeders on tidal flats: influence of local density and tidal elevation. Limnol Oceanogr 32:143-166

Peterson CH, Summerson HC, Fegley SR (1987) Ecological consequences of mechanical harvesting of clams. Fish Bull 85:281-298

Phillips RC, McRoy CP (1980) Handbook of seagrass biology:

Editorial responsibility: Kenneth Heck (Contributing Editor), Dauphin Island, Alabama, USA an ecosystem perspective. Garland STPM, New York Reusch TBH (1998) Native predators contribute to invasion resistance to the non-indigenous bivalve Musculista senhousia in southern California, USA. Mar Ecol Prog Ser 170:159-168

Reusch TBH, Williams SL (1998) Variable responses of native eelgrass Zostera marina to a non-indigenous bivalve Musculista senhousia. Oecologia 113:428-441

Reusch TBH, Williams SL (1999) Macrophyte canopy structure and the success of an invasive marine bivalve. Oikos 84:398-416

Seed R, Suchanek TH (1992) Population and community ecology of Mytilus. In: Gosling E (ed) The mussel Mytilus: ecology, physiology, genetics and culture. Elsevier Science Publishers, Amsterdam, p 87-169

Sewell AT (1996) Eelgrass growth and abundance in an urban estuary: the negative effects of anemone coverage. MS thesis, San Diego State University, San Diego

Short FT, Neckles HA (1999) The effects of global climate change on seagrasses. Aquat Bot 63:169-196

Short FT, Wyllie-Echeverria S (1996) Natural and humaninduced disturbance of seagrasses. Environ Conserv 23: $17-27$

Sokal RR, Rohlf FJ (1995) Biometry, 3rd edn. WH Freeman, New York

Stearns SC (1992) The evolution of life histories. Oxford University Press, Oxford

Strathmann MF (1987) Reproduction and development of marine invertebrates of the northern Pacific coast: data and methods for the study of eggs, embryos, and larvae. University of Washington Press, Seattle

Thayer GW, Kenworthy WJ, Fonseca MS (1984) The ecology of eelgrass meadows of the Atlantic coast: a community profile. US Fish and Wildlife Service, FWS/OBS0-84/02, Washington, DC

Thompson RJ, MacDonald BA (1991) Physiological integrations and energy partitioning. In: Shumway S (ed) Scallops: biology, ecology and aquaculture. Elsevier Science Publishers, Amsterdam, p 347-376

Valle CF, O'Brien JW, Wiese KB (1999) Differential habitat use by California halibut, Paralichthys californicus, barred sand bass, Paralabrax nebulifer, and other juvenile fishes in Alamitos Bay, California. Fish Bull 97:646-660

Wildish DJ, Kristmanson DD (1984) Importance to mussels of the benthic boundary layer. Can J Fish Aquat Sci 41: $1618-1625$

Williams SL (2001) Reduced genetic diversity in eelgrass transplantations affects both population growth and individual fitness. Ecol Appl 11:1472-1488

Williams SL, Heck KL Jr (2001) Seagrass communities. In: Bertness MD, Gaines SD, Hay ME (eds) Marine community ecology. Sinauer Associates, Sunderland, MA, p 317-337

Wilson CA, Beckman DW, Dean JM (1987) Calcein as a fluorescent marker of otoliths of larval and juvenile fish. Trans Am Fish Soc 116:668-670

Winer BJ, Brown DR, Michels KM (1991) Statistical principles in experimental design. MacGraw-Hill, New York

Zimmerman RC, Reguzzoni JL, Wyllie-Echeverria S, Jossely M, Alberte RS (1991) Assessment of environmental suitability for growth of Zostera marina (eelgrass) in San Francisco Bay. Aquat Bot 39:353-366

Submitted: May 4, 2002; Accepted: January 3, 2003

Proofs received from author(s): May 12, 2003 